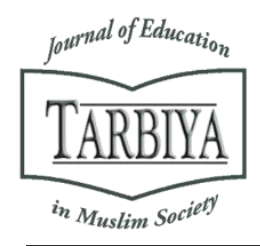

Available online at TARBIYA: Journal of Education in Muslim Society Website:

http://journal.uinjkt.ac.id/index.php/tarbiya

TARBIYA: Journal of Education in Muslim Society, 4(2), 2017, 200-215

\title{
STREET CHILDREN, POOR TOUCH EDUCATION \& PUTTING ATTENTION
}

\author{
Mujahidil Mustaqim \\ Indonesia University of Education, Indonesia \\ E-mail: mujahidil.mustaqim@student.upi.edu
}

Received: $12^{\text {th }}$ September 2017; Revised: $20^{\text {th }}$ November 2017; Accepted: $28^{\text {th }}$ December 2017

\section{Abstract}

The study wanted to explore how much physiological, psychological, family, school and community factors inflence the religiousity of street children in Padang City. This research was conducted in one of the schools that inaugurated the city of Padang as a special education school for urban children especially street children. The type of research is field research by using combination method (mixed method) with sequential explanatory design model type. This study yields the following conclusions: First, the results of quantitative research mention the physiological, psychological, family, school and community influence on the religiosity of learners respectively by $6.3 \%, 17.8 \%, 12.5 \%, 10.2 \%$ and $14.9 \%$. This figure indicates that street children although already formalized education, but considered not have a significant impact on the religiosity of street children. The two qualitative research results describe that the low nominal influence is caused by the various problems of life faced by street children, among them the most dominant are the problems of family disharmony, such as the concern and the poor attention of the parent to the education of the child, the unhealthy family communication, parental divorce, misconduct of children, financial shortage and so on. This then causes poor street children from the values of religiosity. The results of this study provide a clear picture that the street children are still not getting the proper education as children in the usual and massive attention that all circles.

Keywords: determinant factors of education; religiosity; street children

\section{Abstrak}

Penelitian ingin menelusuri seberapa besar faktor fisiologis, psikologis, keluarga, sekolah dan masyarakat terhadap religuisitas anak jalanan di Kota Padang.. Penelitian ini dilakukan di salah satu sekolah yang diresmikan Kota Padang sebagai sekolah pendidikan layanan khusus anak-anak urban perkotaan terutama anak jalanan. Jenis penelitian ini adalah penelitian lapangan dengan menggunakan metode kombinasi (mixed method) dengan jenis model sequential explanatory design. Penelitian ini menghasilkan sejumlah kesimpulan berikut: Pertama, hasil penelitian kuantitatif menyebutkan pengaruh fisiologis, psikologis, keluarga, sekolah dan masyarakat terhadap religiusitas peserta didik masing-masing sebesar $6.3 \%, 17.8 \%$, $12.5 \%, 10.2 \%$ dan 14.9\%. Angka ini menunjukkan bahwa anak jalanan meskipun sudah diformalitaskan pendidikannya, akan tetapi dinilai belum memberi dampak yang signifikan terhadap religiusitas anak jalanan. Kedua hasil penelitian kualitatif mendeskripsikan bahwa rendahnya nominal pengaruh disebabkan karena peliknya berbagai masalah kehidupan yang dihadapi anak jalanan, diantaranya yang paling dominan adalah masalah-masalah ketidakharmonisan keluarga, seperti kepedulian dan perhatian orangtua yang minim terhadap pendidikan anak, komunikasi keluarga yang tidak hangat, perselingkuhan, perceraian orangtua, salah pola asuh, kekurangan finansial dan sebagainya. Hal ini kemudian menyebabkan anak jalanan miskin dari nilai-nilai religiusitas. Hasil penelitian ini memberi gambaran nyata bahwa bahwa anak jalanan masih belum mendapatkan pendidikan yang layak sebagaimana anakanak pada lazimnya dan perhatian yang massif yang semua kalangan.

Kata kunci: faktor determinan pendidikan; religiusitas; anak jalanan

How to Cite : Mustaqim, M. (2017). Street Children, Poor Touch Education \& Putting Attention. TARBIYA: Journal of Education in Muslim Society, 4(2), 200-215. doi:10.15408/tjems.v4i2.7232.

Permalink/DOI: http://dx.doi.org/10.15408/tjems.v4i2.7232 


\section{Introduction}

At the beginning of its development, urbanization in Indonesia was well received by the community. Expectations of people who want to change lives are better moved to urban areas to become factory workers. Revenues into labor turn out to be bigger than farming. The belief that life in urban areas will be more secure than living in rural areas becomes a philosophy of life. Even the philosophy of life is passed down from generation to generation. Therefore, the level of urbanization continues to increase from year to year. Urbanization not only gives a lot of positive impact, but also leaves a negative impact that is not small. The increasing number of workers is not proportional to the existing factories or the higher cost of living in urban areas than the rural areas cause the income earned is no longer large. Not to mention the number of factories that bankrupt or workers who are laid off (Kurnia, 2014). As a result poverty is rampant in urban areas and because of the poverty of street children appear. In the book "Psychosocial Intervention" street children are defined as follows: "a child who spends most of his time earning a living or roaming the streets or other public places (Indonesia, 2001)".

Street children are one of the consequences that arise from urbanization. The problem of the emergence of street children is started from the problem of poverty where the child must go to the streets to finance life. Various forms of livelihood they do, such as singing, selling cigarettes and newspapers in retail on public transport, and others. According to data posted by the Ministry of Social Affairs, in 2009 the number of street children in Indonesia reached 135,139 children and spread in a number of major cities. Meanwhile, in 2014 the number of street children increased relatively high with an estimated number of 230,000 people (Aries, 2013). Lastly, based on data of the Ministry of Social Affairs of the Republic of Indonesia in
2016, the number of street children in Indonesia increased to reach 4.1 million.

This wide range of street children will necessarily lead to various attitudes that are not in accordance with the values and norms prevailing in the community. The life of street children who are very open with a variety of outside influences will be the main cause of street children tend connoted with negative stigma. This can be seen from some information that a number of street children arrested Satpol PP found drunk glue (Alfariz, 2015). Meanwhile, in Kota Padang based on data collected from Satpol PP, most of those arrested ngelem are street children and street singers (Anggara, 2014). Even also found a number of street children who were caught taking drugs (Awaluddin, 2013).

In addition, a number of media reported in addition to the tricky economic life of street children, criminality is also identified to them. Suara Merdeka released that five street children in Bayolali were arrested by police because they found one of the houses (Merdeka, 2015). The Kompas reported that three street children in Semarang were caught stealing the mosque's charity box (Firmansyah, 2015). A number of phenomena above indicate that the role of education on street children has not run and functioning optimally. The educational process as seen only works in children with established economic and social conditions. It seems that street children are on the other side that is relatively not getting enough education attention so that sometimes there is stigma of educational discrimination.

As is known, street children should get an education in shelter. As in the city of Padang according to the data that the author himpun there are at least four shelter homes that are shelters Bina Generasi, Attaqwa Muhammadiyah, Aditya Karya and Mahatayuda (Padang Ekspress, 2011). However, in recent 
years the shelter house is no longer active and its existence is no longer functioning properly. This is because the task and role of Padang City Social Service in handling shelter house no longer running.

"Padang City Social Service has in recent years no longer take part in the handling of shelter homes, including in terms of financing and education. This is based on the phenomenon that street children are more comfortable living on the streets than in shelters. So the program planned by the Social Service for shelter is not running optimally (Padang,2013)."

To check the truth, then the author did observations to the shelter houses. The results of the authors also found the same thing. Based on the author's interview with one of Bina Generasi's terminus, the shelter house no longer runs optimally, and the educational programs offered are rarely followed by street children and street children are rarely living here (Generasi, 2014). Meanwhile, the attic house of Attaqwa Muhammadiyah no longer exists. Educational programs are also no longer there, except for educational programs in Ramadan, such as reciting and breaking the fast together. Itupun also not much attended by street children (Muhammadiyah, 2014).

This means that the shelter house in Padang City has not had a significant impact on street children education. A number of studies also basically mention the same symptoms. Ahmad Saifullah (2009) "Case Study of Islamic Education of Street Children in Green Park Room (RTH) Imam Bonjol Padang" which illustrates that the effort of Islamic education for street children in Padang city is considered not maximal so as not to give a significant influence. This is due to various factors, between the weak economy, the lack of parents, the influence of friends, the family is not harmonious, the desire to have their own money, the parents employ their children as economic resources, the desire to be free, and the role of social institutions is not maximized to handle street children.

Furthermore, Dian Permata Sari (2017) in his research shows that street children empowerment program in Tabayun Tabernacle House has a low level of effectiveness. This conclusion was obtained by analyzing four indicators of effectiveness level of street children empowerment program which include targeting accuracy, success of socialization, achievement of objectives, and program monitoring. The effectiveness of street children empowerment program by accumulating these four indicators, it can be concluded that the effectiveness level of Tabayun Saving House is still in the low category of $46.7 \%$. This can happen because the target, socialization, program objectives and monitoring are still many that have not been achieved. Many street children are returning to the streets after the program, children not returning home with their families, and activities that are not sustainable for children.

Table 1. Number \& Percentage Level of Effectiveness of Street Children Empowerment Program at Tabayun Tabernacle Home, Cibinong Sub-District, Bogor Regency 2016

\begin{tabular}{lll}
\hline $\begin{array}{l}\text { Level } \\
\text { Effectiveness }\end{array}$ & $\begin{array}{l}\text { Total } \\
\text { (n) }\end{array}$ & $\begin{array}{l}\text { Percentage } \\
(\%)\end{array}$ \\
\hline Low & 14 & 46.7 \\
Medium & 10 & 33.3 \\
High & 6 & 20.0 \\
Total & 30 & 100.0 \\
\hline
\end{tabular}

Thus, the role of shelter homes either in the city of Padang or in a big city like the city of Bogor-was not much different that is equally not provide optimal benefits to the sustainability and education of street children. Nevertheless, street children in the city of Padang began to be nurtured and educated on the path of formal education. It is based as informed by the Padang Ekspress newspaper, namely: 
"A total of 5 schools inaugurated as a special education school for urban children urban children, on 7 September 2013 then. In these five schools there is a government program called Anti-Drop Out. Those who are embraced into the Anti-DO School program, are the ones who drop out of school because they can not afford it. Some of them are singing, making money on the streets, until they never think about the classroom bench. Anti-DO special programs, mostly followed by children who have dropped out of school for three to four years for various reasons, especially the family economy. It is estimated that 250 children have been adopted in the program so that every child can attend this school (Padang Ekspress, 2014)."

Street children who are trained through formal education are new in Padang City. Nonactive function of shelter as a means to foster street children, education for street children seems to be transformed into formal education. This means street children who are normally "dinonformalkan" in shelter homes want to "formalized" the school in order to realize the goals of national education. Where the street children are formally trained, then the learning was done formally. Street children who used to be nurtured informally and informally then in five schools that are specifically plotted to foster street children fostered with formal learning. Padang City Government that sends street children must have a strong reason why they are educated in formal education. The writer saw the loss of function of the shelter house became one of the trigger of street children. In addition, the authors also looked at the many cases of street children, such as drunk glue, drugs, and attitude of street children who are not in accordance with the values and norms prevailing in the community even to the crime does not escape the strong reason that street children need to be nurtured serious and maximum. The formal education pathway is a solution to prevent and anticipate and repair street children from cases that ensnare them.

A number of cases that ensnare street children caused by a number of factors, among other broken home, poverty, and daily environment free rule. These factors are trying to overcome by formal education so that cases that ensnare street children can be prevented. In addition to formal education here tasked to alleviate cases of street children then the task of education in the context of Islamic education includes the following five points, namely:

a. Psychological maturity. The task of education is how learners can develop the maturity of cipta (cognition), taste (affection) and karsa (konatif) so that the development of life to be ideal.

b. Biological maturity. The task of education is how learners can know their physical growth and use as they should.

c. Sociological maturity. The task of education is to recognize and practice the ethical code of the local community.

d. Pedagogical maturity. The task of education is how learners can realize their rights and responsibilities and are responsible for their actions.

e. Religious honor. The task of education is how learners can carry out God's commands and stay away from his prohibition when reaching the age of baligh (Abdul Mujib, 2008).

Referring to the above, one of the tasks of Islamic education is to form the religious maturity of learners. Religiusity (adjective) is religious, relates to religion, in accordance with the principles of a religion. Religious (religiousness, noun) the state or quality of a person becomes religious. Religiosity (religiosity, noun) obedience to religion or religion (National, 2000). In another source mentioned 
that religiosity means devotion to religion; piety (Sudarsono, 1993). Religiosity is defined as how far the knowledge, how firm belief, how the implementation of worship and rules and how deep appreciation of the religion it embraces. For a Muslim, religiosity can be known from the extent of knowledge, belief, implementation and appreciation of religion (Fuad Nashori, 2009).

This means one of the tasks of Islamic education in relation to street children is to form the religiosity of street children. However, the presence of a number of street children as described previously indicates that religiosity has not been established in street children. In the context of learning Islamic religious education, religiosity is influenced by five factors, namely physiological, psychological, family, school and community (Shah, 2010). Religiosity as a behavior, then based on the theory of J. B Watson said that the formation of human behavior is the result of the relationship of response and stimulus. Humans are not able to determine behavior without stimulus. Human behavior is passive, and waiting. the stimulus, then the human will respond (Lubis, 2011).

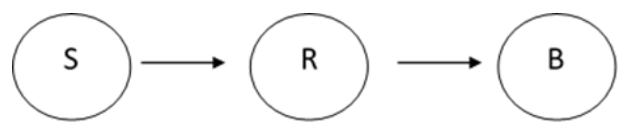

$S=$ stimulus

$\mathrm{R}=$ respons

$\mathrm{B}=$ behaviour

Chart 1 . The Theory of Watson Behavior Formation

Referring to the above theory, religiosity plays as a behaviour. The physiological, psychological, family, school and community plays as a stimulus. Thus, the response is a form of religiosity formed by physiological, psychological, family, school and community. Five factors that become stimulus, the concrete of which can be seen the condition of street children's families. Children go to the streets due to divorced parents factors. This then has great potential for various acts of social aberrion which also directly illustrate the lower sicas of religiosity. Maghfiroh (2015) says that messy parent households can cause children to take to the streets, because they feel nobody is paying attention. The child becomes more confused, and feels emotional uncertainty. Then there arises many inner conflicts so that the child can not stay at home, always feel painful, and embarrassed. To forget all this inner anguish the child vent his anger and aggressiveness into the streets.

A life free from family control or even breaking up with family and wandering in public places is a vulnerable situation for street children to behave deviantly. Various social threats always haunt them. At any time they may be subject to enforcement operations by security personnel, and the control of the city, so that it will get the treatment arbitrarily. Similarly, the arbitrary treatment or acts of violence from street children, because the pattern of free life like that of the law of the jungle. Other social problems that can plot the lives of street children to the black valley of city life include; drinking, drug use, sexually transmitted diseases resulting from free sexual behavior, prostitution and trafficking (Kusmanto, 2013). Stimulus is like a family problem, and poor psychological condition is assessed as potentially to the level of religiosity of street children.

Religiosity as a response and behavior (hahaviour), then the many cases of street children such as drunk glue, drugs even to theft and other criminal acts, this illustrates that the religiosity of street children is questioned. Munawaroh (2000) mentions that the aspect of the practice of religious teachings in street children will be seen from the indications of social attitude of street children that appear for example seen from the level of social violations and also their level of obedience to religious teachings. Furthermore, it is mentioned that street children $65,71 \%$ often do social violation. 
Table 2. Level of Religious Principles of Street Children

\begin{tabular}{lllll}
\hline No & $\begin{array}{l}\text { Social } \\
\text { Abuse }\end{array}$ & N & F & \% \\
\hline $\mathbf{1}$ & High & 35 & 23 & $65,71 \%$ \\
2 & Medium & & 12 & $31,28 \%$ \\
3 & Low/Never & - & - \\
\multicolumn{2}{l}{ Total } & 35 & 35 & 100 \\
\hline
\end{tabular}

In addition, also found that the religious behavior of street children in the city of Salatiga is $50 \%$ of religious behavior or religiitas low street children (Aji, 2010).

Therefore, the touch of low street children education seen from the impact of shelter homes that can not be felt optimally and massively. Poor attention from various parties, especially families, communities and schools that cause them trapped in the abyss of social deviation and criminality. This is then the basis of the writer's foothold to examine how much influence the physiological, psychological, family, school and community as a stimulus to the religiosity of street children.

\section{Method}

The type of research conducted is field research (field research) by using a combination method (mixed method). The type of research method used is a combination of sequential explanatory design model. The object of the research in question is amongst the majority of street children who were built in one of five schools inaugurated by Padang City as a special education school for urban urban children and some educators. Data collection techniques through questionnaires, interviews, observation and documentation studies. Data analysis techniques through quantitative data analysis techniques using multiple linear regression. While the technique of processing and qualitative data analysis is Miles Huberman's version (display, reduction, verification and conclusion). Then the validity testing techniques include credibility test, internal validity, dependability and confirmability (objectivity).

\section{Findings and Discussion}

The study found a number of statistical data reinforced by direct interviews and observations on the ground in order to reinforce the truth of the statistics that emerged. First, we describe the level of influence that occurs either partially or simultaneously between the predictor variables to the consequent variables and then will be further elaborated why the level of influence found is small with the measurements of the interviews, direct observation and documentation. The level of influence of physiological, psychological, family, school and community factors on the religiosity of street children in Padang City can be formulated as follows:

\section{Result of Quantitative Research Findings}

Table 3 The Influence of Physiological, Psychological, Family, School and Society

Factors on Religiusity Street Children

Coefficients $^{\mathrm{a}}$

\begin{tabular}{llllll}
\hline Model & \multicolumn{2}{l}{$\begin{array}{l}\text { Unstandardized } \\
\text { Coefficients }\end{array}$} & \multicolumn{2}{l}{$\begin{array}{l}\text { StandardizedT } \\
\text { Coefficients }\end{array}$} & \multirow{2}{*}{ Sig. } \\
\cline { 2 - 5 } & B & Std. Error & Beta & \\
\hline (Constant) & 1.761 & .548 & & 3.213 & .002 \\
fisiologis & .049 & .135 & .063 & .361 & .720 \\
psikologis & .236 & .268 & .178 & .881 & .383 \\
keluarga & -.101 & .188 & -.125 & -.534 & .596 \\
sekolah & .109 & .187 & .102 & .583 & .563 \\
masyarakat & .139 & .181 & .149 & .769 & .446 \\
\hline
\end{tabular}

Dependent Variable: religiusitas

\section{- The Effect of Physiological Factors on the Religiosity of Street Children}

Based on the above table can be explained that there is a significant influence between the physiological to the religiosity of street children. Based on the sig column. with sig price. for 0.720 and if consulted at the level of $5 \%$ then 
$0.720>0.05$. This means alternative hypothesis (Ha) is rejected and null hypothesis (Ho) accepted stating that there is no significant influence between physiological factors with the religiosity of street children. Based on the column $\beta$ then obtained the amount of beta (coefficient) path of physiological variables on the religiosity of street children is 0.063 or $6.3 \%$. The price of this influence is considered very small and reinforces the hypothesis that there is no significant influence between physiological factors with the religiosity of street children. That is, there is not no effect of physiological factors on the religiosity of street children but the effect is very small at $6.3 \%$ so that assessed as small influence is considered not to give a significant influence.

\section{- The Effect of Psychologicals Factors on the Religiosity of Street Children}

Based on the above table can be explained that there is a significant influence between the psychological on the religiosity of street children. Based on the sig column. with sig price. of 0.383 and if consulted at the level of $5 \%$ then $0.383>$ 0.05. This means that $\mathrm{Ha}$ is rejected and Ho accepted that there is no significant influence between psychological factors and the religiosity of street children. Based on the column $\beta$ then obtained the amount of beta (coefficient) path psychological variables on the religiosity of street children is 0.178 or $17.8 \%$. The price of this effect is small and reinforces the hypothesis that there is no significant influence between psychological factors and the religiosity of street children. That is, there is no effect of psychological factors on the religiosity of street children, but this small influence is $17.8 \%$ so it is considered this small influence is considered not to give a significant effect.
- The Effect of Families Factors on the Religiosity of Street Children

Based on the above table can be explained that there is a significant influence between families on the religiosity of street children. Based on the sig column. with sig price. of 0.596 and when consulted at the 5\% level then $0.596>$ 0.05. This means $\mathrm{Ha}$ is rejected and $\mathrm{Ho}$ accepted stating that there is no significant influence between family factors with the religiosity of street children. Based on the column $\beta$ then obtained the amount of beta (coefficient) of the family variable path to the religiosity of street children is 0.125 or $12.5 \%$. The price of this influence is small and reinforces the hypothesis that there is no significant influence between family factors and the religiosity of street children. That is, there is no influence of family factors on the religiosity of street children but the effect is very small once that $12.5 \%$ so assessed this small influence is considered not to give a significant effect.

- The Effect of Schools Factors on the Religiosity of Street Children

Based on the above table can be explained that there is a significant influence between schools on the religiosity of street children. Based on the sig column. with sig price. amounted to 0.563 and if consulted at the 5\% level then $0.563>0.05$. This means that $\mathrm{Ha}$ is rejected and Ho accepted that there is no significant influence between the school factor and the religiosity of the street children. Based on the column $\beta$ then obtained the amount of beta (coefficient) of the school variable path to the religiosity of street children is 0.102 or by $10.2 \%$. The price of this influence is small and reinforces the hypothesis that there is no significant influence between school factors and the religiosity of street children. That is, there is no effect of school factors on the religiosity of street children but the effect is very small once that is $10.2 \%$ so it is 
considered this small influence is considered not to give a significant effect.

\section{- The Effect of Community Factors on the Religiosity of Street Children}

Based on the above table can be explained that there is a significant influence between the community on the religiosity of street children. Based on the sig column. with sig price. of 0.446 and if consulted at the level of 5\% then $0.446>$ 0.05. This means $\mathrm{Ha}$ is rejected and $\mathrm{Ho}$ accepted stating that there is no significant influence between the factor of society with the religiosity of street children. Based on the column $\beta$ then obtained the amount of beta (coefficient) path of society variable to the religiosity of street children is 0.149 or $14.9 \%$. The price of this influence is highly valued and reinforces the hypothesis that there is no significant influence between the factors of society and the religiosity of street children. That is, there is no influence of the society factor on the religiosity of street children but the small influence is $14.9 \%$ so it is considered this small influence is considered not to give a significant effect.

\section{Result of Quantitative Research Findings}

\section{- The Effect of Physiological Factors on the Religiosity of Street Children}

The first aspect studied affects the religiosity of learners is physiological. The physiological aspects are closely related to the health of the body, and the condition of the student's special organs. Body health can be seen from the fitness of the body, such as dizziness, lethargy, sleepiness, and others. Meanwhile, the condition of special organs can be seen from the level of sight and hearing sensory health or experiencing disability of one member of the body, such as deafness, blindness, broken leg, broken arm, paralysis and others (Slameto, 2010).

Referring to the explanation Slameto, it can be understood that the physiological learners closely related to two things, namely the health of the body and the completeness of the limbs. To obtain a healthy body certainly supply enough food at least based on the four healthy standard five perfect. Especially in adolescence where physical growth is very rapid where it requires energy intake in accordance with the level or level of physical growth of learners. Zulkifli (2009) sees physical growth in adolescence undergoing rapid changes, faster than in childhood and adulthood. To keep up with that rapid growth, teenagers need to eat and sleep more. Trying to uncover how the physiological condition of learners who become one of the factors that influence religiosity or in the context of a qualitative approach called looking for meaning from the point of view of some educators in schools that made the object of research, seen in the following phenomena:

1) Learners who are usually late to school spend their sleep time with things that should not be done by children who are still in school age. This conclusion was obtained based on the interview of the writer along with the picket teacher with the learner who arrived late, namely:

"Why are you often late for school? Ask the teacher to the child. They replied: Father, we play cards almost every night, and come home at dawn call time or 6 or 7 hours just go home to pack. That's why we're late for school, sir. After that, we go to bed and just go to school. Therefore, we arrived at school at 9 am, sir. they say directly without much thought", said a group of learners.

2) Street children who are nurtured in some schools that are specifically plotted by the Padang City government generally 
come from families who are not able to financially. It is spoken by all teachers. After all, this school is one of them for children who can not afford school. To prove the truth of this matter, the author digs information to learners and educators.

"We usually singing to help parents make a living, after school, sir. One day at most can be 200 thousand rupiah or at least 50 thousand rupiah, sir. The income of our singing parcels to parents, sir, said some street children who work as street children."

This is justified by some of the educators among them, Silat masters and the field of study of Islamic Education (PAI). In addition, the authors found the students were not only singing is not a single job that the street children live in providing personal and family. According to the Ministry of Social Affairs of Indonesia (2001), the indicator of street children according to the activities of street children is to have activities such as shoe polishing, bagging, poking, newspapers or magazines, car wiping, car washing, scavenging, porters, leasing umbrellas, being liaison or service providers to help financially family.

Street children who go to school in one of the schools specially provided by the government of Padang City is scattering various jobs such as parking attendants, ngasong, motor wash, coolies. In fact there are also a small percentage of learners who are undergoing jobs that are not included in the category of street children work, such as fishermen, welders, and gallon waterman.

"The children who study here are many stories that make the heart sad and cry when told. Someone helped his parents sell coffee in the city park, or helped his parents become fishermen, workshops, motor washers, parking attendants, and even coolies, one teacher's story."

In addition, he said surprisingly, "Even the saddest, they ask for money to the father / mother teacher because there is no cost to go home and the cost of going to school tomorrow". Then given money sincerely by one of the educators in the hope that money should not be reversed. After getting information from educators, the author really find some learners who are working as told informants, including Edo who works as a car parker at Simpang Haru Market. In addition, some children who the author recognizes his face as a learner where they are washing the motor at the front motor wash Andalas Andalas Andalas Grand Mosque and mengasong in the market.

3) The authors found there are some learners who consume addictive substances, such as cigarettes not at the time outside school hours but during school hours. Even the authors found there are learners who suck glue during school hours.

Consuming such substances can cause deterioration of the child's health in both short and long periods. The consequences in the short period that resulted is a headache and generate the effects of flying even unconscious. One of the educators on this matter expressed as follows:

"Street children are fostered here is very difficult to be formed his character. They smoke when the teacher does not come, or breaks or asks for permission when learning is taking place. They usually smoke and even suck glue in the school bathroom. Even more sad, it is also found consuming a number of tranquilizers because of the complexity of life problems they face."

Referring to the various phenomena above indicate physiological condition of street children is very concern so that writer looked with various phenomenon above explains 
religiosity is not seen in student self. So true the influence of physiological factors on the religiosity of street children is very small that is $6.3 \%$. Due to their unhealthy physical condition by consuming unhealthy foods so it is only natural that the values of religiosity are not visible to them. The rapid physical growth in adolescence that should be balanced with healthy food and adequate sleep but instead filled with substances and unhealthy behavior. Physiological conditions such as this very not possible the process of learning, especially Islamic religious education is expected so that the expected results of religiosity.

Therefore, efforts need to improve the religiosity of street children so that the level of addictive consuming behavior can be reduced. Based on a national survey of young people conducted by Chu (2007) found that religiosity can significantly depress young people from the use and dismissal of drug consumption. This can be seen from the following expression:

Data derived from Wave 5 to Wave 7 of the National Youth Survey are employed to test whether religiosity exerts an effect on initiation of and desistance from drug use. The findings suggest religious behavior has a direct effect on individuals' desistance from marijuana and harddrug use. Religious behavior at Wave 7 had a somewhat stronger deterrent effect on hard-drug use than on marijuana use. Frequent participation in religious activities at Wave 7 raised the odds of being a nonuser of hard drugs by about $371 \%$. For people who used hard drugs at either Wave 5 or Wave 6 or at both waves, regular participation in religious activities at Wave 7 increased the odds of being desisters by about $167 \%$.

Therefore, in order for the physiological condition of street children to be healthy, a healthy environment becomes the most basic need for street children. Astri (2016) considers this need to be considered very basic because the various activities performed by street children outside the home actually bring risks to the physical condition and health of street children. The cost to eat is difficult, especially to think about the allocation of funds in case of illness in the future. On the other hand a risky life on the highway, such as full of pollution, scorching heat, rain, also greatly affect their physical condition. The condition of the houses under the bridge and poor sanitation, causing street children are very susceptible to diseases such as skin diseases, respiratory infections, and diarrhea. In addition, they are also susceptible to contracting sexually transmitted diseases due to promiscuity with the opposite sex and high risk groups transmit the disease.

Eric Neumayer (2003) of the Department of Geography and Environment, London School of Economics and Political Science, states that state policy has an effect on the number of violent crimes, especially murder. His study of 117 countries during the 1980 to 1997 period proved that government policies that provide guarantees for democratization, human rights, economic growth, increased levels of income, economic justice (welfare) and no significant incidence of income, can reduce crime rates violence occurring in a country. For that, Referring to Neumayer thinking, should the government not position the child as the perpetrator in the misbehavior that he did. Prochild welfare policies will not create conditions that require children to be street children or commit crimes, as a form of adaptation of children in earning money to meet their needs (Sulhin, 2012).

This reality justifies the theory of Abraham Moslow who argues that the formation of human behavior is the result of the needs of the self, such as physiological needs, security, selfesteem, social and self-actualization (Lubis, 2011). Physiological conditions, such as spending the night with playing cards where it 
should be filled with enough study and sleep, life in the orphanage is very limited, financial parents who do not support for children's education so that the child must also support themselves and family even sad because not enough money for schools, there are children who must commit criminal acts, and children who take addictive substances that even have reached the level of addicted or dependent effect, all this explains that the physiological needs of learners are not met so that the birth tendency to take action actions that violate community values and norms. If physiological needs like this then there is a commonplace if the religiosity of learners is not present in the daily behavior of learners.

\section{- Effect of Psychological Factors, Family and School on the Religiosity of Learners}

One of the factors that most attention in this research is psychological and family. In this study, the authors found that psychological learners tend to be problematic. Based on the educator's view the root of the problem is the family. When there are problems related to the student's family then at that time it also arises the psychological problems of learners. Then the family and psychological problems are tried by teachers in certain schools in Padang City that are specially prepared to handle street children.

Herri Zan Pieter (2011) reveals psychological changes in adolescence include four things, namely intellectual change and interests (social interest, recreation, selfperformance, achievement, money, independence, occupation, education, religion, status symbols, and sex), emotions and social behavior. Four things will be seen in the street children's family issues explaining what their psychological condition is like.

1) The authors found the majority of learners here are typical learners who have problems in the form of family disharmony or broken home. This affects the psychological learners so that religiosity is also influenced.

Broken home is a major problem facing educators. The majority of educators argue that the cause of the presence of various problems in the students themselves is started from a broken home. Broken home experienced by street children is not caused by a single factor but the various factors that lie behind. So complicated this problem, an educator argues that $80 \%$ of children here have problems with their divorced parents. Divorce is the first cause of the occurrence of broken home. Some teachers reveal parental divorce of learners is a major obstacle in educating street children. Many of the children's stories told the teacher that they had to face the ordeal of seeing their parents quarrel, cheating, divorced until many times and remarried. The stories that the author wants to interprest here.

The high parental divorce phenomenon experienced by street children illustrates that the level of care of parents to children is considered very less. As a result, there are various kinds of problems in children, such as consuming addictive substances with the aim of calming their hearts and minds. Another result that the authors find is the low learning motivation. This is evident from the often late school, low intention to read and learn, and tends to take action that is opposed by the teacher.

2) In addition to the phenomenon of broken home, the author also found another phenomenon that also relates to parents, namely poverty. As explained earlier, the majority of street children who are trained also contribute to providing for their personal and family life. The following will be described further the phenomenon of financial limitations of street children resulting in lack of study time, learning motivation and social deviation and other 
consequences. Some educators say that some children who rarely attend school even up to two months do not go to school because they help parents to market, wash motor and other jobs.

Reality as described above indicates many things. These indications lead to parents as the main actors in the effort to educate children. First, moving from a number of divorce phenomenon of street children parent directly depict loss of family role in forming child religiosity. How do children want and be able to obey religion while their parents cheat, divorce, quarrel and remarry. Divorce, arguments cause parents to not direct and guide their children to pray, worship with discipline, behave according to religious norms and customs of society and others. Then this reality justifies the small influence of the family on the religiosity of street children is only 12,5

In addition, parental awareness of the growth of children is considered less including the awareness of children's education. Parents are more concerned with each other's ego. Parental ego this impact on the inaction of parents in running family functions. The family can only perform its function as a bilological or reproductive function consequently other functions are neglected. Whereas M.I Soelaiman thought that a family should be able to run 8 family functions, such as education function, socialization function, protection function, affection function, religious function, economic function, recreation function, biological function (in Shochib, 2007). When starting from the phenomenon of divorce and also the poverty that plagued the family of learners where the child must be the backbone of the parents to meet the needs of family life it will be found the economic function of the family is also able to run properly. Children who should spend more time to learn. But the fact is, not so. Sadly, due to the financial inadequacy of the parents, the child chooses to work to support the family rather than the school. More sad, there are children who have to commit criminal acts because the cost to go to school does not exist.

Then, based on the phenomenon of divorce parents also illustrates that the parental awareness of child growth is considered less also illustrates that the child experienced a parenting pattern. Lack of parental concern symbolizes parenting for children is an indulgent parenting pattern. Indulgent parenting is a parenting style in which parents engage with their children but gives only a few limitations on them. Such parents let their children do what they want (Laura, 2010). The busyness of parents working unconsciously also can shape what kind of parenting that applied to the child regardless of whether busy work is an effort to meet the needs of families who have not enough or sufficient needs of families that have been fulfilled.

Foster care is something that must be considered. Do not let the wrong pattern to make children do things that deviate and destructive. Just as doctors are wrong in prescribing patients. The results of Masyithoh (2017) show students who are raised with good democratic parenting well with high and low emotional intelligence acquiring high social skills. And vice versa. Thus, policewomen are very influential on the development of competence of children. Therefore, the role of parents is very large on the regiusitas child. The issue of divorce, an unpleasant family atmosphere and not conducive to learning, causes the child's potential for deviant acts. Of course, the religiosity of children is very doubtful. So Duriez, Soenens, \& Neyrinck (2009) through his article "Religiosity related to better parenting" states that:

parents who process religious contents in a symbolic way endorse an "inner orientation" when it comes to existential issues, they are likely (a) to attach importance to intrinsic goals and to 
promote such goals and (b) to reject goals with an outward orientation. Moreover, a number of studies have shown that parental religiosity is positively related to child conformity.

In the daily life of religiosity, this statement can be interpreted that the parent who has a religious attitude then when something objectionary comes, say something destructive, the parent (a) directs the child to a wellpurposed and educational activity (b) ) reject the things that aimlessly contain no useful elements or even activities that damage the personality of the child. Meanwhile, parents who are far from the values of religiosity, then very afraid the opposite will happen.

For that, so that children have a religious attitude, parents must first have a religious understanding and attitude. Parents play a major role in shaping child's religiosity. As is stated above, that parental religiosity is positively related to child conformity. Even the other opinion asserts that "the degree of social enforcement of religiosity in a country of conscience and religious intrinsic personal motives" (Stavrova \& Siegers, 2013). From here, we can conclude that the level of child religiosity, the adherence of children to the teachings of religion is very dependent on the level of religiosity and the level of parental obedience to religious teachings.

One of the causes of today's low level of religiosity is the effect of industrialization that began in 1990 and the growing secularization in many countries. Though the survey in 1981 mentioned that the level of religiosity in certain countries is still good. This is stated in the following statement:

Since 1981, theWorld Values Survey has interviewed nationally representative samples of 18-24-year-olds in 81 countries on four occasions. North American young people reported religious beliefs at higher rates than did young people from those in other developed countries, but at lower rates than did those in developing countries. For the importance of religion in one's life, young people's reports ranged from $5.6 \%$ in Germany to $47.2 \%$ in the United States to $100 \%$ in Indonesia, whereas for the importance of God in one's life, results ranged from $1.8 \%$ in Japan to $50.3 \%$ in the United States to $100 \%$ in Pakistan. Lastly, most young people believed in God, such that scores ranged from $40.4 \%$ in Sweden to $92.9 \%$ in the United States to $100 \%$ in Egypt. Since 1990 the importance of religion has declined for young people from the most industrialized nations, resulting in increased secularization (Barry et al., 2010).

Second, due to the various problems above, psychological street children become problematic. This is reflected in various variations of students' negative behavior, ranging from undisciplined, disobedient, difficult to receive advice, spending the night supposedly for breaks by playing cards, consuming addictive substances, almost falling into the very things that are prohibited by religion, irregular lifestyle and even up to criminal acts and others. Thus, such phenomena support the results of quantitative studies that the small psychological influence on the religiosity of street children is $17.8 \%$. The number and complexity of psychological problems, and families cause the religiosity of street children are not formed optimally.

Third, the authors see the function of schools is not used as a place to learn but more for a place to vent various problems and berantya life they live. Counseling Guidance Counselor (BK) on this subject said that "They are not happy at home. There is no laughing atmosphere with parents at home. Parents are busy working or fighting or cheating and getting divorced. So they are more comfortable in school with teachers, friends. Because at school they can joke 
with each other, joke with friends and fill time with fun activities at school. Even when school time is over, they stay in school spending time with friends. "Other educators also say," Kids to school is not for learning but to talk to teachers. They complain about a solution for their divorced parents, quarreling and other problems.

Sharing their feelings becomes a daily reality in school that is often encountered. Street children are very comfortable to be in school because they can vent various family issues and complicated life to the teacher. As a result, the teacher not only plays the role of teacher only but more likely to the counselor. This is the right and solutive action that the teacher performs. Results of research conducted by Hikmawati (2016) mentions that counseling can increase the religious commitment of learners with significant amount of $47.37 \%$. Islamic religious education counseling can enhance the religiosity of learners in the areas of belief, Islam and exclusion.

This is the essential teacher's role. Teachers are not only limited to the transfer of knowledge that can also be done by inanimate objects but much more than that. Teachers educate something abstract that can not be handled by inanimate objects technologically advanced. The teacher educates the hearts of the learner to teach what is good and bad. A figure capable of becoming an intruder of the inner learners. The figure who sincerely sincerely is beside the students with all the problems and anxiety of life especially street children. So Nata (2014) mentions in his research one of the ideal teacher indicators of affective aspect is able to bring the physical and inner unity.

Observations by the author do also justify this. Some learners form groups when out of the game or or educators do not come or even when school hours are out sitting on the school terrace joking. More than that, some learners are also easily familiar with the author even though they just know each other, they vent about personal issues. Thus, the school function has not touched on the aspect of establishment of street children religiosity. The function of the school is more to the place and to provide solutions to the psychological impact of children who are destroyed due to family divorce issues and the like. As a result, the school's influence on the religiosity of street children is still small at $10.2 \%$.

For that, the coordination of parents and schools should be more intense and serious. Given the complexity of the problem faced by street children. Divorce and other family persolan should be avoided and minimized by parents. So parents can focus more on educating children by building a harmonious coordination with the school. Faizuddin (2016) argued that between teachers and parents there should be a positive interaction to improve the competence of children. Teachers must understand that educating children alone is not effective. Teachers should work with parents to understand the child's condition.

\section{Conclusion}

There are always many things that can be expressed in research where studying a thing is different from the commonplace, that is, certain things that are marginalized in life. Things like these can usually people inspiration to do better and useful for the country. No exception to this research is to examine the street children with one thousand complexity of life issues. In outline, street children street life is usually not separated from the influence of five subjects, namely physiological, psychological, family, school and community. This study tried to reveal the religiosity of street children studied from these five conditions: 1) The physiological influence on the religiosity of street children is 0.063 or $6.3 \%$; 2) The psychological influence on the religiosity of street children is 0.178 or 
$17.8 \%$; 3) The influence of family on the religiosity of street children is 0.125 or $12.5 \%$; 4) The influence of school on the religiosity of street children is 0.102 or $10.2 \%$; 5)The influence of society on the religiosity of street children is 0.149 or $14.9 \%$;

The results of qualitative studies justifying the results of quantitative studies conducted before that these five factors do not contribute a large influence on the religiosity of learners. The small nominal of these five factors is clearly illustrated in the complexity of life problems of street children, such as poverty, parental divorce, broken home and misconduct. As a result the religiosity of learners is not visible in everyday life. This can be seen from a variety of behavior, such as smoking, ngelem, taking drugs during school hours, learning motivation including low religion, even to the scope of criminality and others. The results of this study provide a clear picture that the street children are still not getting the proper education as children in the usual and massive attention that all circles.

\section{References}

Abdul Mujib, J. M. (2008). Ilmu Pendidikan Islam. Jakata: Kencana Prenada Media Group.

Aji, G. B. (2010). Pengaruh Keberagamaan terhadap Perilaku Menyimpang Anak Jalanan di Kota Salatiga.

Alfariz. (2015, April 6). Berita Jawa Tengah. Retrieved from Berita Jawa Tengah: http://beritajateng.net/berita-jatengterbaru-hari-ini/asik-mabuk-lem-enamanak-jalanan-diciduk-satpol-pp/21206

Anggara, N. (2014, Oktober 12). Koran Padang Ekspres. Retrieved from Koran Padang Ekspres:

http://www.koran.padek.co/read/detail/79 59

Aries, M. (2013, Oktober 10). Republika. Retrieved from Republika: http://www.republika.co.id/berita/nasional /umum/13/10/10/mugfnp-indonesiabebas-anjal-di-2014

Astri, H. (2016). Kehidupan Anak Jalanan di Indonesia: Faktor Penyebab, Tatanan Hidup dan Kerentanan Berperilaku Menyimpang. Jurnal Aspirasi (Trial), 5(2), 145-155.

Awaluddin. (2013, Oktober 9). Okezone. Retrieved from Okezone: http://news.okezone.com/read/2013/10/0 9/500/879352/selinting-ganja-dijual-rp7ribu-ke-anak-jalanan-di-tol-kebon-jeruk

Barry, C. M., Nelson, L., Davarya, S., Urry, S., Barry, C. M., Nelson, L., ... Urry, S. (2010). Religiosity and Spirituality during the Transition to Adulthood. https://doi.org/10.1177/01650254093509 64

Chu, D. C. (2007). From Drug Use, 34(5), 661-679. https://doi.org/10.1177/ 0093854806293485

Duriez, B., Soenens, B., \& Neyrinck, B. (2009). Is Religiosity Related to Better Parenting, 1287-1307.

Faizuddin, A., An-Nuaimy, T., \& Irzal, M. (2016). An Analysis of Factors Influencing Parents in the Selection of Schools. TARBIYA: Journal of Education in Muslim Society, 3(1), 90-95.

Firmansyah. (2015, Maret 27). Kompas. Retrieved from Kompas: http://regional.kompas.com/read/2015/03 /27/18051861/tiga.anak.jalanan.tertangka p. mencurikotakamal.masjid

Fuad Nashori, R. D. (2009). Mengembangkan Kreativitas Dalam Perspektif Psikologi Islami. Jogjakarta: Menara Kudus.

Generasi, P. R. (2014, Januari 10). Pembinaan Anak Jalanan di Ruman Singgah Bina Generasi Kota Padang. (M. Mustaqim, Interviewer)

Hikmawati, F. (2016). Psychoeducation of Character Personal's Local Wisdom of Sundanese People's Behaviour in Internalizing Religious Commitment. TARBIYA: Journal of Education in Muslim Society, 3(1), 64-76. 
Indonesia, D. S. (2001). Intervensi Psikososial. Jakarta: Direktorat Kesejahteraan Anak Keluarga dan Usia Lanjut.

Indonesia, D. S. (2011). Koran Harian Padang Ekspress. Padang.

Indonesia, D. S. (2014). Koran Harian Padang Ekspress. Padang.

Kurnia. (2014, Oktober 23). Kementerian Sosial. Retrieved from Kementerian Sosial: http://puspensos.kemsos.go.id/modules.ph p? name $=$ News $\&$ file $=$ article $\&$ sid $=101$

Kusmanto, T. Y. (2013). Mereka yang Tercerabut dari Masa Depannya: Analisis Sosiologis Problem Sosial Anak di Indonesia. Sawwa: Jurnal Studi Gender dan Anak, 8(2), 225-244.

Laura, K. (2010). Psikologi Umum: Sebuah Pandangan Apresiatif. Jakarta: Salemba Humanika.

Lubis, H. Z. (2011). Pengantar Psikologi untuk Kebidanan. Jakarta: Kencana Prenada Media Group.

Maghfiroh, I. (2015). Pembinaan Agama Islam Terhadap Anak Jalanan di Rumah Perlindungan Sosial Berbasis Masyarakat (Rpsbm) Kota Pekalongan. Doctoral dissertation. STAIN Pekalongan.

Masyithoh, S. (2017). The Influence of Parents' Parenting and Emotional Quotient on Students' Social Skills. TARBIYA: Journal of Education in Muslim Society, 4(1), 3244.

Muhammadiyah, P. R. (2014, Januari 11). Pembinaan Anak Jalanan di Rumah Singgah Attaqwa Muhammadiyah Kota Padang. (M. Mustaqim, Interviewer)

Munawaroh, A. (2000). Pengaruh Pendidikan Agama Islam Terhadap Sikap Sosial Anak Jalanan di Rumah Singgah Darul Hikmah Kalijaten Taman Sidoarjo. Doctoral dissertation. UIN Sunan Ampel Surabaya.

Nasional, D. P. (2000). Kamus Besar Bahasa Indonesia, Edisi Ketiga. Jakarta: Balai Pustaka.

Nata, A., \& Sofyan, A. (2014). Pengembangan Desain Model Pembelajaran PAI Berbasis Karakter Mulia yang Holistik, Humanis,
Emansipatoris, dan Efektif. TARBIYA: Journal of Education in Muslim Society, 1(1), 35-50.

Newmayer, E. (2003). Good Policy Can Lower Violent Crime: Evidence from a CrossNational Panel of Homicide Rates. Journal of Peace Research, Vol. 40 No. 60.

Padang, P. D. (2013, Desember 26 ). Rumah Singgah dan Anak Jalanan. (M. Mustaqim, Interviewer)

Saifullah, A. (2009). Skripsi; Pendidikan Agama Islam Anak Jalanan di Ruang Taman Hijau (RTH) Imam Bonjol Padang. Padang: Fakultas Tarbiyah dan Keguruan IAIN Imam Bonjol Padang.

Sari, D. P. (2017). Analisis Program Pemberdayaan Anak Jalanan di Rumah Singgah Tabayun, Kecamatan Cibinong, Kabupaten Bogor.

Shochib. (2007). Pola Asuh Orang Tua untuk Membantu Anak Mengembangkan Disiplin Diri. Jakarta: PT Rineka Cipta.

Slameto. (2010). Belajar dan Faktor-faktor yang Mempengaruhi. Jakarta: Rineke Cipta.

Stavrova, O., \& Siegers, P. (2013). Religious Prosociality and Morality Across Cultures: How Social Enforcement of Religion Shapes the Effects of Personal Religiosity on Prosocial and Moral Attitudes and Behaviors.

https://doi.org/10.1177/01461672135109 51

Suara Merdeka. (2015, Mei 15). Retrieved from Suara Merdeka: http://berita.suaramerdeka.com/smcetak/ mencuri-lima-anak-jalanan-diamankan/

Sudarsono. (1993). Kamus Filsafat dan Psikologi . Jakarta: Rineka Cipta.

Sulhin, I. (2012). Kemiskinan, kebijakan negara dan kenakalan anak. Jurnal Kriminologi Indonesia, 3(3).

Syah, M. (2010). Psikologi Pendidikan dengan Pendekatan Baru. Bandung: PT. Remaja Rosadakarya.

Zulkifli. (2009). Psikologi Perkembangan. Bandung: PT. Remaja Rosdakarya. 